AL-AMWAL: JURNAL EKONOMI DAN PERBANKAN SYARI'AH (2021) Vol 13: $46-63$

DOI: 10.24235/amwal.v13i1.7969

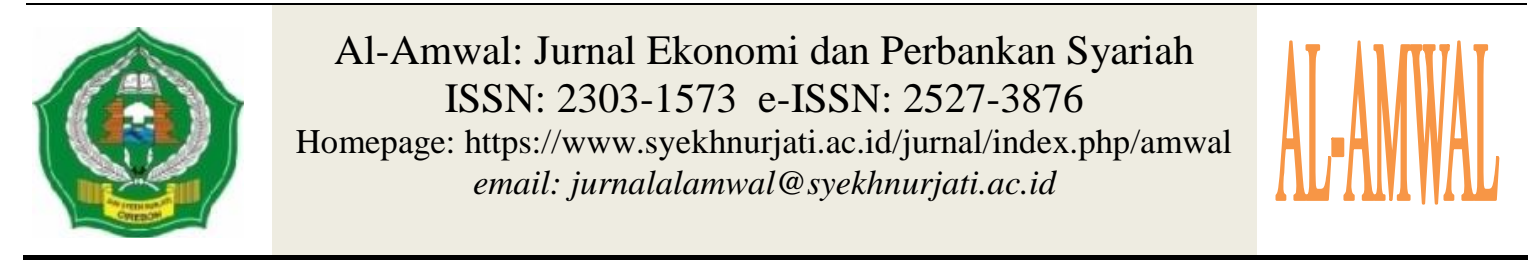

\title{
Factors Affecting Purchase Decision of Halal Processed Meat for Muslim Consumers in Semarang
}

\author{
Aulisa Lintang Usmandani \\ Islamic Economics, Diponegoro University \\ Email: lintangaulisaa@gmail.com \\ Darwanto \\ Islamic Economics, Diponegoro University \\ Email: darwanto78@lecturer.undip.co.id
}

\begin{abstract}
This research analyzes price perception, product quality, halal awareness, halal certification, and halal marketing as factors affecting purchase decision through purchase intention as an intervening variable. The data collected through a questionnaire survey consisting of 130 Muslim consumers in Semarang who purchased halal processed meat products use Structural Equation Model - AMOS analysis. The results of the analysis show that price perception has an insignificant effect on purchase intention and purchase decision. The product quality has a significant effect on purchase intention and an insignificant effect on purchase decision. Halal awareness has a significant effect on purchase intention and an insignificant effect on purchase decision. Halal certification has a significant effect on purchase intention and an insignificant effect on purchase decision. Halal marketing has a significant effect on purchase intention and an insignificant effect on purchase decision. The effect of mediation, quality product towards purchase decision through purchase intention as an intervening variable can mediate as a full mediation.
\end{abstract}

Keywords: Product Quality, Purchase Intention, Purchase Decision, Intervening, SEM.

\begin{abstract}
Abstrak
Penelitian ini bertujuan untuk menganalisis pengaruh persepsi harga, kualitas produk, kesadaran halal, sertifikasi halal, dan pemasaran halal sebagai factor-faktor yang mempengaruhi keputusan pembelian produk olahan daging halal pada konsumen muslim di Kota Semarang melalui minat beli sebagai variabel intervening. Adapun
\end{abstract}


metode pengumpulan dara diperoleh melalui kuesioner. Populasi penelitian ini yaitu masyarakat Muslim Kota Semarang yang pernah melakukan pembelian produk olahan daging halal dengan sampel sebanyak 130 responden. Teknik analisis yang digunakan adalah Structural Equaton Modeling - AMOS. Hasil analisis menunjukkan bahwa persepsi harga tidak berpengaruh terhadap minat beli maupun keputusan pembelian. Kualitas produk berpengaruh signifikan terhadap minat beli dan tidak signifikan terhadap keputusan pembelian. Kesadaran halal tidak signifikan terhadap minat beli dan signifikan terhadap keputusan pembelian. Sertifikasi halal berpengaruh signifikan terhadap minat beli dan tidak signifikan terhadap keputusan pembelian. Pemasaran halal berpengaruh signifikan terhadap minat beli dan tidak signifikan terhadap keputusan pembelian. Pengaruh mediasi terbukti pada pengaruh kualitas produk terhadap keputusan pembelian melalui minat beli sebagai variabel intervening yang mampu dimediasi secara full mediation.

Kata kunci: Kualitas Produk, Minat Beli, Keputusan Pembelian, Intervening, SEM.

\section{INTRODUCTION}

Muslim population in Indonesia reaches $207,176,162$ people or $87.18 \%$ of the total population (BPS, 2010). Indonesia is a consumer of halal products with the majority of the Muslim population who is obliged to consume halal products, especially food products. In 2017, Indonesia as the country with the largest Muslim population in the world amounting to the US\$218.8 billion in various sectors of the global Islamic economy which increased from 11th to 10th position, overtaking Brunei Darussalam, this increase was supported by increased events and press coverage that led to increase awareness regarding halal food (Thomson Reuters \& DinarStandard, 2018).

Table 1. The Population of Indonesia by Religious Community

\begin{tabular}{lcc}
\hline Religion & $\begin{array}{c}\text { Population } \\
\text { (People) }\end{array}$ & $\begin{array}{c}\text { Percentage } \\
(\%)\end{array}$ \\
\hline Islam & $207,176,162$ & 87.18 \\
Kristen & $16,528,513$ & 6.96 \\
Katolik & $6,907,873$ & 2.91 \\
Hindu & $4,012,116$ & 1.69 \\
Budha & $1,703,254$ & 0.72 \\
Khong Hu Chu & 117,091 & 0.05 \\
Others & 299,617 & 0.13 \\
Not Answered & 139,582 & 0.06 \\
Not Asked & 757,118 & 0.32 \\
\hline Total & $\mathbf{2 3 7 , 6 4 1 , 3 2 6}$ & $\mathbf{1 0 0}$ \\
\hline
\end{tabular}

Sumber: Population Census, 2010.

Mannan (1997) emphasizes the nature of consumer behavior that is not excessive, Islam also emphasizes behavior to prioritize the interests of others, namely the consumer. The moderate attitude in consumer behavior then becomes logical in the Islamic consumption style, which is relative and dynamic. Allah has set certain limits on 
human behavior so that it benefits the individual without sacrificing the rights of other individuals, as stipulated in Sharia law (as-Syari'ah) (Rianto \& Amalia, 2014).

In 2019 the consumption for food of the Indonesian people was $49.14 \%$ with a value of 572,551 rupiah/capita/month, where the level of consumption participation for processed meat products increased from $27.31 \%$ to $31.04 \%$ in 2018 to 2019 (BPS, 2019). The increase in demand for processed meat products indicates that the meat processing industry also needs to increase the supply of imported meat as raw material for processed meat products. Halal processed meat also comes from halal raw materials, including the slaughtering process and the tools used must comply with the rules of the Sharia law.

Central Java with a level of food consumption reaching 49.08\% (BPS, 2019). The Semarang City Population and Civil Registration Service (2019) noted that the population of Semarang as the capital of Central Java reached 1,674,358 people with the majority of the Muslim population reaching 1,350,310 people (BPS, 2017). Muslim consumers need to pay attention to the halalness of food products to consumed, especially with the news about changes to the rules that imported meat not required to labeled and certified as halal in the Regulation of the Minister of Trade in 29/2019, which previously regulated in 59/2016. Besides, there is a concern that the existence of a mixture of halal meat with haram meat "oplosan" as raw material for processed meat products is also the responsibility of LPPOM MUI in carrying out a supervisory role in processed meat products circulating in Muslim communities.

Fatwas of the Indonesian Council of Ulama (MUI) stated that processed products aoften doubted about their halalness or sanctity so that intensive investigation and examination needed before deciding on the halal status of a product as an effort to protect consumers, especially Muslim consumers. Halal does not only cover religious aspects but is closely related to the production process that pays attention to the quality and cleanliness of a product. The government plays an important role in paying attention that the circulation of food products has halal standards by Islamic law (Yussof, 2004).

Price perception studied by (Ariffin et al., 2019), shows that there is a positive relationship between price and interest in buying halal food. The result differs from (Lee $\&$ Yun, 2015) that price has a negative and significant effect on purchase intention. While, price perception does not affect purchase decision (Angraini \& Harwani, 2020) and (Rachmawati \& Muflikhati, 2017) and (Widyastuti \& Said, 2017).

Product Quality studied by (Maichum et al., 2017), shows that halal quality has a positive and significant effect on consumer buying interest. This contradicts with (Aziz \& Chok, 2013) that the relationship between food quality and purchase intention is not significant. While, product quality shows that product quality has a significant effect on purchasing decisions (Nafilah et al., 2015). The results contradicts with (Tawas \& Pandensolang, 2015) that indicates product quality has no effect on purchasing decisions.

Halal Awareness studied by (Syukur \& Nimsai, 2018), shows that halal awareness has a positive and significant effect. While research by (Awan et al., 2015) and (Nurcahyo \& Hudrasyah, 2017) showed the different results that halal awareness has no influence on interest in halal products. Halal Awareness of Muslim consumers has a significant effect on purchasing decisions (Hamdan et al., 2013) and (Muslichah et al., 2019) 
Halal Certification has a positive effect on consumer buying interest (Setyaningsih \& Marwansyah, 2019). In comparison, the research results by (Huda \& Muchlisin, 2014) shows that the halal label as the MUI halal certification logo on product packaging has no influence on purchase intention. Halal label as an indicator of the fulfillment of halal certification affects purchasing decisions (Anggadwita et al., 2020). This results contradicts with (Aspan et al., 2017) that the halal label is an indicator of halal-certified products and has no effect on purchasing decisions.

Halal Marketing has the highest contribution in influencing the buying interest of Muslim consumers (Awan et al., 2015). However, research by (Nurhasanah et al., 2018), shows that halal marketing has a negative and significant effect on purchase intention. Promotion as an indicator in marketing has a significant effect on purchasing decisions (Umah \& Herianingrum, 2018). Differences with research results by (Khuwaroh et al., 2018), shows that promotion as an indicator in halal marketing has no effect. against purchasing decisions.

Purchase intention as a variable intervening on purchasing decisions has a significant effect (Rahmaningtyas et al., 2017) and (Fauzia et al., 2019). Therefore, this study will analyze the effect of price perception, product quality, halal awareness, halal certification, and halal marketing toward purchase decision of halal processed meat, with purchase intention as an intervening variable.

\section{LITERATURE REVIEW Price Perception}

Peter and Olson (2013) perception of price is how consumers understand thoroughly the price information and can provide deep meaning for consumers. In a narrow sense, price is the amount charged for a good or service. In a broad sense, price is the sum of the total values of the benefits that consumers exchange by having or using a good or service. Price is a factor that influences consumer purchases (Kotler and Armstrong, 2012).

\section{Product Quality}

Aziz and Chok (2013) suggested 2 perspectives related to food quality. From a halal perspective, the requirements of food quality must be safe, healthy, and hygienic. In a general perspective, the food quality terms of the products offered are superior to competing products or according to food products desired by consumers.

\section{Halal Awareness}

Ambali and Bakar (2014) stated that awareness is human perception and cognitive reactions regarding what is eaten, drunk, and used. Subjectively, consciousness is a state in which a person consciously, semi-consciously, or in an unconscious state can understand the halal aspects allowed by Allah SWT. Muslim consumers in making decisions to buy halal-certified food products tend to consider internal factors such as age, religious obligations, feelings of security, and the belief in getting blessings. This shows that the awareness of Muslim consumers comes from a belief in themselves (Ayuniyyah et al., 2017).

\section{Halal Certification}

Decree of the Minister of Agriculture No.745/KPTS/TN.240/12/1992 concerning Requirements and Supervision of Importation of Meat from Abroad in Law No.18 of 
2012 of Article 97 states everyone who produces food domestically for trade is required to include a label on the packaging including halal label or halal sign for those required. The import of meat for public consumption based on livestock that slaughtered, according to Islamic law and stated in a halal certificate. The Halal MUI certificate is a written fatwa of the Indonesian Council of Ulama, which states the halalness of a product is by Islamic law. Halal MUI certificate is a condition for obtaining permission to include halal labels on product packaging from authorized government institutions.

Halal certification is a guarantee of safety for Muslims to be able to consume a product as evidenced by the inclusion of a halal label on the product packaging (Aziz and Chok, 2013). The inclusion of a halal label on product packaging has shown that the government, in this case, the LPPOM MUI is serious about protecting Muslim consumers in Indonesia.

\section{Halal Marketing}

Varinli et al. (2016) argued that the literature on halal marketing is still limited. However, elements of halal products in the marketing mix are the main elements in halal marketing. Products as the basis for the marketing mix so that all decisions on halal products affect other components of the marketing mix such as price, place, and promotion. The existence of mass media and public relations on halal marketing due to the terms "Islam" and "Halal" is potential, but marketers need to synchronize promotional ethics to be in line with the products being marketed (Farlina, 2017).

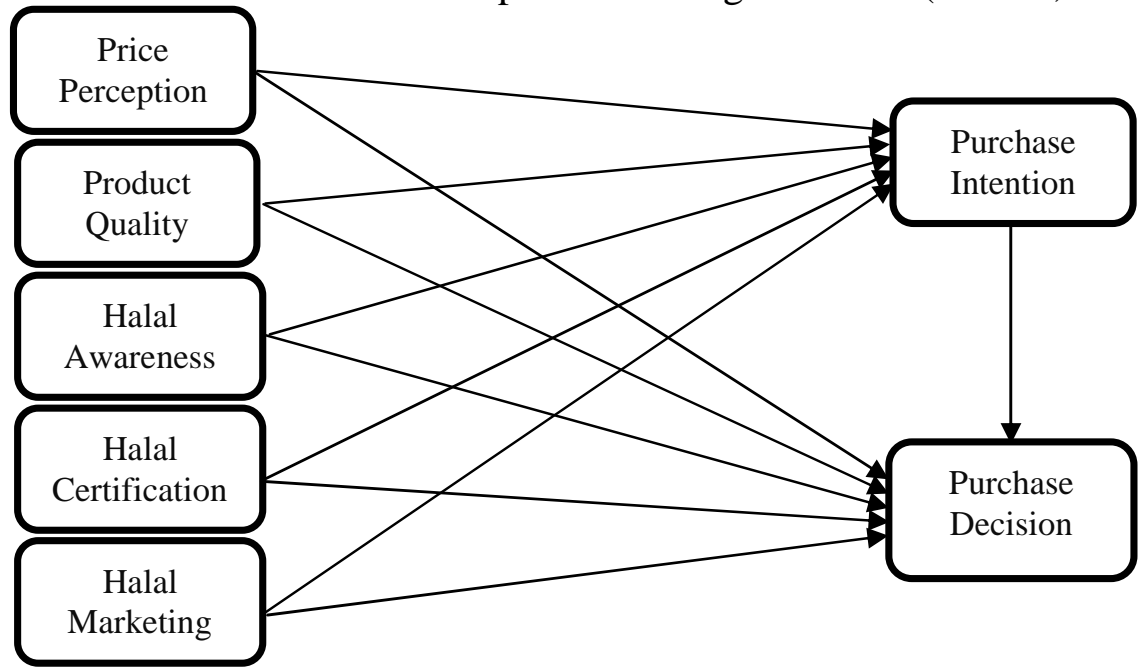

Figure 1. Theoretical Framework

Based on the theoretical framework above, the hypotheses are as follows:

H1: Price Perception has a significant effect on Purchase Intention.

H2: Price Perception has a significant effect on Purchase Decision.

H3: Product Quality has a significant effect on Purchase Intention.

H4: Product Quality has a significant effect on Purchase Decision.

H5: Halal Awareness has a significant effect on Purchase Intention.

H6: Halal Awareness has a significant effect on Purchase Decision.

H7: Halal Certification has a significant effect on Purchase Intention.

H8: Halal Certification has a significant effect on Purchase Decision.

H9: Halal Marketing has a significant effect on Purchase Intention.

H10: Halal Marketing has a significant effect on Purchase Decision.

H11: Purchase Intention has a significant effect on Purchase Decision. 


\section{METHOD}

This research is a quantitative study. The data were collected using an online questionnaire using a 5 Likert scale $(1=$ strongly disagree to $5=$ strongly agree). The questionnaire distributed to 130 respondents, who are Muslim consumers in Semarang who have bought processed halal meat products using the technique purposive nonprobability sampling. Data analysis used Structural Equation Modeling (SEM) and analysis of the effect of mediation used the Sobel Test. This research uses 7 variables, including price perception, product quality, halal awareness, halal certification, halal marketing, purchase intention, and purchase decision.

\section{Table 2. Indicators of Research Variables}

\begin{tabular}{|c|c|}
\hline Variable & Indicators \\
\hline $\begin{array}{l}\text { Price Perception (X1) } \\
\text { (Ariffin } \text { et al., 2019; } \\
\text { Phan and Mai, 2016) }\end{array}$ & $\begin{array}{l}\text { 1. Price is the main consideration before } \\
\text { buying halal food products; } \\
\text { 2. Consider the current affordable halal food } \\
\text { products; } \\
\text { 3. Compare prices on several halal food } \\
\text { products. }\end{array}$ \\
\hline $\begin{array}{l}\text { Product Quality (X2) } \\
\text { (Yunus et al., 2014; } \\
\text { Maichum et al., 2017) }\end{array}$ & $\begin{array}{l}\text { 1. Quality of halal food products; } \\
\text { 2. Halal food products have good and } \\
\text { consistent quality standards; } \\
\text { 3. The ingredients used in halal food products } \\
\text { reflect the safety and quality of the products. }\end{array}$ \\
\hline $\begin{array}{l}\text { Halal Awareness (X3) } \\
\text { (Ambali and Bakar, } \\
\text { 2014; Awan et.al., 2015) }\end{array}$ & $\begin{array}{l}\text { 1. Understanding of halal food products; } \\
\text { 2. Knowledge of raw materials, additives, } \\
\text { and processing of halal food products; } \\
\text { 3. The government/ halal authorities are } \\
\text { responsible for the availability of halal food } \\
\text { product; } \\
\text { 4. Producers are responsible for the } \\
\text { availability of halal food products; } \\
\text { 5. Supermarkets/minimarkets are responsible } \\
\text { for the availability of halal food products. }\end{array}$ \\
\hline $\begin{array}{l}\text { Halal Certification (X4) } \\
\text { (Aziz and Chok, 2013; } \\
\text { Shaari and Arifin, 2010) }\end{array}$ & $\begin{array}{l}\text { 1. Knowing the halal certification and logo } \\
\text { on the product's packaging; } \\
\text { 2. Choosing products based on the halal logo; } \\
\text { 3. Be careful when choosing products with } \\
\text { the halal logo; } \\
\text { 4. Knowing about the fake halal logo. }\end{array}$ \\
\hline $\begin{array}{l}\text { Halal Marketing (X5) } \\
\text { (Aziz and Chok, 2013; } \\
\text { Awan et.al., 2015) }\end{array}$ & $\begin{array}{l}\text { 1. Brands on halal food products; } \\
\text { 2. Sales promotion on halal food products; } \\
\text { 3. Discount on halal food products. }\end{array}$ \\
\hline $\begin{array}{l}\text { Purchase Intention (Y) } \\
\text { (Rois, 2016) }\end{array}$ & $\begin{array}{l}\text { 1. The desire to find information about halal } \\
\text { food products; } \\
\text { 2. The desire to try halal food products; } \\
\text { 3. The desire to have halal food products; } \\
\text { 4. The desire to buy halal food products. }\end{array}$ \\
\hline $\begin{array}{l}\text { Purchase Decision }(Z) \\
\text { (Ayuniyyah et al., 2017; }\end{array}$ & $\begin{array}{l}\text { 1. Buying halal food products is the right } \\
\text { choice; }\end{array}$ \\
\hline
\end{tabular}




\begin{tabular}{ll}
\hline \multicolumn{1}{c}{ Variable } & \multicolumn{1}{c}{ Indicators } \\
\hline Aziz and Chok, 2013) & $\begin{array}{l}\text { 2. People around me choose to buy halal food } \\
\text { products; } \\
\text { 3. Repurchase halal food products in the } \\
\text { future; } \\
\text { 4. Recommend to others to buy halal food } \\
\text { products. }\end{array}$ \\
\hline
\end{tabular}

\section{RESULTS AND DISCUSSION \\ Characteristics of Respondents}

This study conducted through an online questionnaire that distributed over 2 weeks to obtain 181 respondents, but 51 respondents did not comply with the required criteria. So this research used 130 respondents with the criteria of respondents include:

1. Muslim consumers in Semarang.

2. Aged $\geq 17$ years.

3. Have bought halal processed meat products at least once in the past month.

Table 3. Characteristics of Respondents

\begin{tabular}{|c|c|c|c|}
\hline Characteristics & Description & $\begin{array}{c}\text { Population } \\
\text { (people) }\end{array}$ & $\begin{array}{c}\text { Percentage } \\
(\%)\end{array}$ \\
\hline \multirow[t]{5}{*}{ Districts } & Semarang Barat & 26 & 20 \\
\hline & Semarang Pusat & 26 & 20 \\
\hline & Semarang Selatan & 26 & 20 \\
\hline & Semarang Timur & 26 & 20 \\
\hline & Semarang Utara & 26 & 20 \\
\hline \multirow[t]{2}{*}{ Gender } & Male & 44 & 33.8 \\
\hline & Female & 86 & 66.2 \\
\hline \multirow[t]{6}{*}{ Age } & $\leq 20$ & 30 & 23.1 \\
\hline & $21-30$ & 25 & 19.2 \\
\hline & $31-40$ & 16 & 12.3 \\
\hline & $41-50$ & 51 & 39.2 \\
\hline & $51-60$ & 7 & 5.4 \\
\hline & $\geq 60$ & 1 & 0.8 \\
\hline \multirow[t]{4}{*}{ Education } & SMA & 47 & 36.2 \\
\hline & D3/D4 & 18 & 13.8 \\
\hline & $\mathrm{S} 1 / \mathrm{S} 2 / \mathrm{S} 3$ & 63 & 48.5 \\
\hline & Others & 2 & 1.5 \\
\hline \multirow[t]{7}{*}{ Profession } & Student & 14 & 10.8 \\
\hline & College Student & 25 & 19.2 \\
\hline & Entrepreneur & 20 & 15.4 \\
\hline & Government Employees & 10 & 7.7 \\
\hline & Private Employees & 33 & 25.4 \\
\hline & Housewife & 20 & 15.4 \\
\hline & Others & 8 & 6.1 \\
\hline \multirow{3}{*}{$\begin{array}{l}\text { Food Expenditure } \\
\text { per Month }\end{array}$} & $<\operatorname{Rp} 1,500,000$ & 49 & 37.7 \\
\hline & $\operatorname{Rp} 1,500,000-\operatorname{Rp} 5,000,000$ & 66 & 50.8 \\
\hline & Rp 5,000,000 - Rp 10,000,000 & 15 & 11.5 \\
\hline
\end{tabular}

Source: Primary data processed, 2020.

Based on the districts, as many as 130 participating respondents, 26 respondents (20\%) distributed in each district of Semarang. Based on gender, the majority of respondents were female as many as 86 respondents $(66.2 \%)$. Based on age, the majority of respondents were between 41-50 years old (39.2\%). Based on education, 
most respondents have an educational background of S1/S2/S3 (48.5\%) and high school education $(36.2 \%)$. Based on jobs, most respondents have jobs as private employees (25.4\%), students (19.2\%), housewives (15.4\%), entrepreneurs (15.4\%), college students $(10.8 \%)$, government employees $(7.7 \%)$, and others $(6.1 \%)$. Based on food expenditure per month, it was dominated by respondents who had a monthly food expenditure of Rp. 1,500,000 - Rp. 5,000,000 (50.8\%).

\section{Analysis of Structural Equation Modeling (SEM)}

Structural Equation Modeling (SEM) is a combination of two separate statistical methods and a set of statistical results that allows the simultaneous testing of a relatively complex set of relationships. SEM modeling consists of a Measurement Model, which is a measurement model to confirm a dimension or factor based on empirical indicators and a Structural Model is a model regarding the structure of relationships that form or explain causality between factors or constructs or variables.

\section{Measurement Model}

Measurement Model in modeling SEM is a measurement model to confirm a dimension or factor based on empirical indicators. In this study, there are independent variables, namely Price Perception, Product Quality, Halal Awareness, Halal Certification, and Halal Marketing has 18 indicators. The intervening variable, Purchase Intention has 4 indicators. The dependent variable, Purchase Decision has 4 indicators. The results of the measurement model shown through the criteria Goodness of Fit found in Chi-Square, Probability, CMIN/DF, CFI, GFI, RMSEA, AGFI, and TLI.

\section{Confirmatory Factor Analysis}

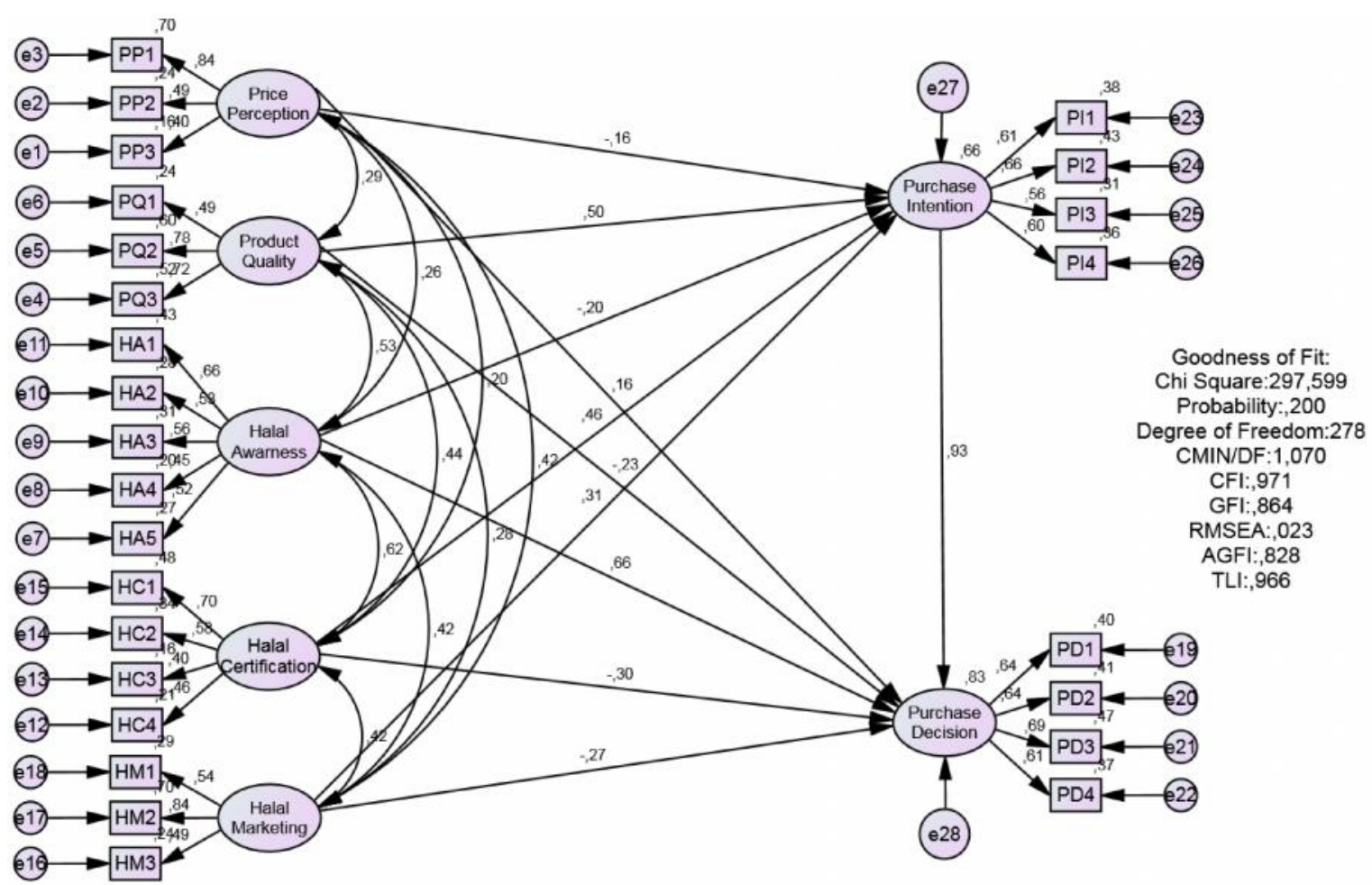

Figure 2. Confirmatory Factor Analysis 
Table 4. Criteria of Goodness of Fit

\begin{tabular}{lccc}
\hline \multicolumn{1}{c}{ Goodness of Fit } & Cut-off Value & Analysis Result & Model Evaluation \\
\hline Chi-Square $(\mathrm{df}=278)$ & $\leq 317.888$ & 297.599 & Good \\
Probability & $\geq 0.05$ & 0.200 & Good \\
CMIN/DF & $\leq 2.00$ & 1.070 & Good \\
CFI & $\geq 0.95$ & 0.971 & Good \\
GFI & $\geq 0.90$ & 0.864 & Marginal \\
RMSEA & $\leq 0.08$ & 0.023 & Good \\
AGFI & $\geq 0.90$ & 0.828 & Marginal \\
TLI & $\geq 0.95$ & 0.966 & Good \\
\hline
\end{tabular}

Source: Primary data processed, 2020.

Table 4 shows that Chi-Square is $297.599(\alpha=0.05$ and $\mathrm{df}=278)$, probability (0.200), CMIN/DF (1.070), CFI (0.971), GFI (0.864), RMSEA (0.023), AGFI (0.828), and TLI (0.966). The model is already in good fit criteria, but there are some indices in marginal criteria.

Furthermore, testing the validity can be seen from the value loading factor > 0.40 on each indicator of the latent variables. Reliability testing can be seen from the construct reliability and average variance extracted. The recommended value for construct reliability is $\mathrm{CR} \geq 0.70$ and for average variance extracted, namely AVE $\geq$ 0.50 .

Table 5. Value of Standard Loading, Construct Reliability, and AVE

\begin{tabular}{|c|c|c|c|c|}
\hline Variable & Indicators & $\begin{array}{l}\text { Standard } \\
\text { Loading }\end{array}$ & $\begin{array}{l}\text { Construct } \\
\text { Reliability }\end{array}$ & $\begin{array}{c}\text { Average } \\
\text { Variance } \\
\text { Extracted } \\
\text { (AVE) }\end{array}$ \\
\hline \multirow[t]{3}{*}{ Price Perception } & PP1 & 0.400 & \multirow{3}{*}{0.610} & \multirow{3}{*}{0.336} \\
\hline & PP2 & 0.487 & & \\
\hline & PP3 & 0.837 & & \\
\hline \multirow[t]{3}{*}{ Product Quality } & PQ1 & 0.719 & \multirow{3}{*}{0.705} & \multirow{3}{*}{0.452} \\
\hline & PQ2 & 0.776 & & \\
\hline & PQ3 & 0.487 & & \\
\hline \multirow[t]{5}{*}{ Halal Awareness } & HA1 & 0.516 & \multirow{5}{*}{0.677} & \multirow{5}{*}{0.299} \\
\hline & HA2 & 0.446 & & \\
\hline & HA3 & 0.561 & & \\
\hline & HA4 & 0.533 & & \\
\hline & HA5 & 0.657 & & \\
\hline \multirow[t]{4}{*}{ Halal Certification } & $\mathrm{HC} 1$ & 0.456 & \multirow{4}{*}{0.618} & \multirow{4}{*}{0.297} \\
\hline & $\mathrm{HC} 2$ & 0.400 & & \\
\hline & $\mathrm{HC} 3$ & 0.581 & & \\
\hline & $\mathrm{HC} 4$ & 0.696 & & \\
\hline \multirow[t]{3}{*}{ Halal Marketing } & HM1 & 0.490 & \multirow{3}{*}{0.663} & \multirow{3}{*}{0.410} \\
\hline & HM2 & 0.836 & & \\
\hline & HM3 & 0.539 & & \\
\hline \multirow[t]{4}{*}{ Purchase Intention } & PI1 & 0.635 & \multirow{4}{*}{0.702} & \multirow{4}{*}{0.371} \\
\hline & PI2 & 0.636 & & \\
\hline & PI3 & 0.689 & & \\
\hline & PI4 & 0.609 & & \\
\hline \multirow[t]{4}{*}{ Purchase Decision } & PD1 & 0.613 & \multirow{4}{*}{0.738} & \multirow{4}{*}{0.413} \\
\hline & PD2 & 0.659 & & \\
\hline & PD3 & 0.561 & & \\
\hline & PD4 & 0.600 & & \\
\hline
\end{tabular}

Source: Primary data processed, 2020. 
Table 5 shows that all indicators are declared valid because they have met the value loading factor $>0.40$. Furthermore, the construct reliability value is more than 0.70 on Product Quality (0.705), Purchase Intention (0.702), and Purchase Decision (0.738) can be ideal because it is by the recommended value. Other results show that Price Perception (0.610), Halal Awareness (0.677), Halal Certification (0.618), and Halal Marketing (0.663), where the CR value lies between 0.60 - 0.70 is still acceptable (Hair et al., 2009).

The AVE value in the variable indicates Price Perception (0.366), Product Quality (0.452), Halal Awareness (0.299), Halal Certification (0.297), Halal Marketing (0.410), Purchase Intention (0.371), and Purchase Decision (0.413), where the AVE value $<0.50$ on all variables is below the recommended value, it is still acceptable as long as the construct reliability value is above 0.60 (Fornell and Larcker, 1981).

\section{Evaluation of Assumptions Structural Equation Modeling (SEM) Evaluation of Data Normality}

Evaluation of data normality shown in the assessment of normality that the data normally distributed with critical ratios on skewness values and multivariate that do not exceed the absolute value \pm 2.58 .

\section{Evaluation of Multivariate Outliers}

The value of Mahalanobis distance $42.956<54.052(\alpha=0.001$ and $\mathrm{df}=26)$, so it can be concluded that there are no multivariate outliers.

\section{Evaluation of Multicollinearity and Singularity}

The determinant of sample covariance matrix value is 0.0000000000037 , so it can be concluded that multicollinearity and singularity are not found in the research model.

\section{Evaluation of Residual Values}

All of the residual values are below the value of \pm 2.58 .

\section{Discussion}

Hypothesis testing based on the structural equations contained in the value Critical Ratio (CR $\geq 1.96)$ and the sig. value $(\mathrm{p} \leq 0.05)$. Table 7 shows the coefficient values that can be made of the following structural equation:

Purchase Intention $=-0.274$ Price Perception +0.485 Product Quality - 0.268 Halal Awareness + 0.690 Halal Certification + 0.363 Halal Marketing +

Purchase Decision $=0.221$ Perceived Price -0.187 Product Quality +0.724 Halal Awareness - 0.371 Halal Certification - 0.253 Halal Marketing + 0.760 Purchase Intention + 
Table 7. Regression Weights SEM Model

\begin{tabular}{|c|c|c|c|c|c|}
\hline \multicolumn{2}{|c|}{ Hypotheses } & \multirow{2}{*}{$\begin{array}{r}\text { Estimate } \\
-0.274\end{array}$} & \multirow{2}{*}{$\begin{array}{l}\text { C.R } \\
-1.181\end{array}$} & \multirow{2}{*}{$\begin{array}{l}\mathbf{P} \\
0.237\end{array}$} & \multirow{2}{*}{$\begin{array}{l}\text { Results } \\
\text { Rejected }\end{array}$} \\
\hline H1 & $\begin{array}{l}\text { Price Perception } \rightarrow \\
\text { Purchase Intention }\end{array}$ & & & & \\
\hline $\mathrm{H} 2$ & $\begin{array}{l}\text { Price Perception } \rightarrow \\
\text { Purchase Decision }\end{array}$ & 0.221 & 0.992 & 0.321 & Rejected \\
\hline $\mathrm{H} 3$ & $\begin{array}{l}\text { Product Quality } \rightarrow \\
\text { Purchase Intention }\end{array}$ & 0.485 & 3.165 & 0.002 & Accepted \\
\hline $\mathrm{H} 4$ & $\begin{array}{l}\text { Product Quality } \rightarrow \\
\text { Purchase Decision }\end{array}$ & -0.187 & -0.195 & 0.360 & Rejected \\
\hline H5 & $\begin{array}{l}\text { Halal Awareness } \rightarrow \\
\text { Purchase Intention }\end{array}$ & -0.268 & -1.047 & 0.295 & Rejected \\
\hline H6 & $\begin{array}{l}\text { Halal Awareness } \rightarrow \\
\text { Purchase Decision }\end{array}$ & 0.724 & 2.464 & 0.014 & Accepted \\
\hline $\mathrm{H} 7$ & $\begin{array}{l}\text { Halal Certification } \rightarrow \\
\text { Purchase Intention }\end{array}$ & 0.690 & 2.054 & 0.040 & Accepted \\
\hline $\mathrm{H} 8$ & $\begin{array}{l}\text { Halal Certification } \rightarrow \\
\text { Purchase Decision }\end{array}$ & -0.371 & -1.014 & 0.311 & Rejected \\
\hline H9 & $\begin{array}{l}\text { Halal Marketing } \rightarrow \\
\text { Purchase Intention }\end{array}$ & 0.363 & 2.022 & 0.043 & Accepted \\
\hline $\mathrm{H} 10$ & $\begin{array}{l}\text { Halal Marketing } \rightarrow \\
\text { Purchase Decision }\end{array}$ & -0.253 & -1.308 & 0.191 & Rejected \\
\hline H11 & $\begin{array}{l}\text { Purchase Intention } \rightarrow \\
\text { Purchase Decision }\end{array}$ & 0.760 & 2.560 & 0.010 & Accepted \\
\hline
\end{tabular}

Source: Primary data processed, 2020.

\section{The Effect of Price Perception on Purchase Decision through Purchase Intention}

The effect of price perception on purchase decision shows that there is no influence between price perception on purchase decision. Angraini and Harwani (2020) argue that price perception does not affect purchase decision. Rachmawati and Muflikhati (2017) show that price perception significantly affects purchase decision.

Price perception is not a reference for consumers in making decisions in buying processed halal meat products. Tjiptono (2002) argues that consumers often have the view that price is used as an indicator of the value of the benefits provided by a good or service. If the benefits felt by consumers increase, the value of the goods or services will increase. Consumers expect prices that are proportional to the quality of the product from the purchases they make (Hadi, 2007). The price of halal processed meat products is not proportional to the quality of products, the consumer will decide not to buy the product.

The effect of price perception on purchase intention shows that there is no effect between price perception and purchase intention. Syukur and Nimsai (2018) argue that price does not affect buying intention. Muslim consumers do not consider prices because they understand that in the process of producing halal food there are costs such as the cost of selecting raw materials and special tools according to the Sharia law, as well as costs for halal certification, which causes the high price of halal food. The perception of Muslim consumers that price is the main consideration when a consumer is interested in trying halal processed meat products, if the price of halal processed meat products is high but the quality of the product is not comparable, it will reduce the buying interest of Muslim consumers. The higher the perception of a high price will influence consumers not to buy the product (Lee and Yun, 2015). 
The Sobel test to test for the effect of mediation cannot be calculated because the effect of price perception on purchase intention is not significant, although the effect of purchase intention as an intervening variable on purchase decision is significant.

\section{The Effect of Product Quality on Purchase Decision through Purchase Intention}

The effect of product quality on purchase decision shows there is no influence between product quality on purchase decision. Tawas and Pandensolang (2015) argue that product quality does not affect purchase decision. Muslim consumers pay attention to good and consistent quality standards, so if the quality of processed meat products is not good and inconsistent, it cause Muslim consumers will not to repurchase processed meat products in the future. This is contrary to Nafilah et al. (2015) which shows that product quality has a significant effect on urchase decision.

The effect of product quality on purchase intention indicates that there is a significant influence between product quality and purchase intention. Maichum et al. (2017) and Satria (2017) argue that the quality of halal has a significant effect on consumer purchase intention. The important thing that Muslim consumers must attended to is good and consistent quality standards to attract consumers to try these processed meat products.

Purchase intention as an intervening variable shows that there is a significant influence between purchase intention on purchase decision. To test the effect of mediation used Sobel test with formula following:

$$
\begin{aligned}
\mathrm{Sab} & =\sqrt{\mathrm{b}^{2} \mathrm{Sa}^{2}+\mathrm{a}^{2} \mathrm{Sb}^{2}+\mathrm{Sa}^{2} \mathrm{Sb}^{2}} \\
& =\sqrt{(0.760)^{2}(0.153)^{2}+(0.485)^{2}(0.297)^{2}+(0.153)^{2}(0.297)^{2}} \\
& =\sqrt{(0.578)(0.023)+(0.235)(0.088)+(0.023)(0.088)} \\
& =\sqrt{(0.014)+(0.021)+(0.002)} \\
& =\sqrt{0.036} \\
& =0.191 \\
\mathrm{t} & =\frac{\mathrm{ab}}{\mathrm{Sab}}=\frac{0.369}{0.191}=1.934
\end{aligned}
$$

The results of the above calculation show that $\mathrm{t}$-calculate $>\mathrm{t}$-table is 1.934> $1.657(\alpha=0.05$ and $\mathrm{df}=130)$, so it can be concluded that purchase intention can mediate the effect of product quality on purchase decision as full mediation. This contrary to Nafilah et al.(2015) which shows that purchase intention is not able to mediate product quality on purchase decision.

\section{The Effect of Halal Awareness on Purchase Decision through Purchase Intention}

The effect of halal awareness on purchase decision shows that there is a direct significant influence between halal awareness and purchase decision. Hamdan et al. (2013) and Setyaningsih and Marwansyah (2019) stated that the halal awareness of Muslim consumers has a significant effect on purchase decision.

The effect of halal awareness on purchase intention shows that there is no influence between halal awareness and purchase intention. Awan et al. (2015) argue that halal awareness does not affect the interest in halal products. A Muslim consumes halal 
food not only because they are aware of it, but also because it is an obligation according to the rules of Sharia law. Muslim consumers have understood the principles of Halalan Thayyiban, but they still do not attend to whether the processed meat products circulating in the community are truly halal with the halal logo of LPPOM MUI.

The Sobel test to test for the effect of mediation cannot be calculated because the relationship between halal awareness and purchase intention is not significant, although the relationship between purchase intention as an intervening variable on purchase decision is significant.

\section{The Effect of Halal Certification on Purchase Decision through Purchase Intention}

The effect of halal certification on purchase decision shows that there is no influence between halal certification on purchase decision. Aspan et al. (2017) argue that the halal label which is an indicator of halal-certified products does not affect purchase decision. Muslim consumers know the importance of the LPPOM MUI halal logo on product packaging, but they still question whether halal food is always given a halal logo. In other words, can food that does not have a halal logo be said to be haram because of the large number of packaged foods without a halal logo circulating in the community (Huda and Muchlisin, 2014).

The effect of halal certification on purchase intention shows that there is a significant influence between halal certification and a positive effect on purchase intention. This is supported by Awan et al. (2015) and Aziz and Chok (2013) that halal certification has a significant effect on purchase intention in halal food products.

Purchase intention as an intervening variable shows that there is a significant influence between purchase intention on purchase decision. To test the effect of mediation, used Sobel test with formula following:

$$
\begin{aligned}
\mathrm{Sab} & =\sqrt{\mathrm{b}^{2} \mathrm{Sa}^{2}+\mathrm{a}^{2} \mathrm{Sb}^{2}+\mathrm{Sa}^{2} \mathrm{Sb}^{2}} \\
& =\sqrt{(0.760)^{2}(0.336)^{2}+(0.690)^{2}(0.297)^{2}+(0.336)^{2}(0.297)^{2}} \\
& =\sqrt{(0.578)(0.113)+(0.476)(0.088)+(0.113)(0.088)} \\
& =\sqrt{(0.065)+(0.042)+(0.010)} \\
& =\sqrt{0.117} \\
& =0.342 \\
\mathrm{t} & =\frac{\mathrm{ab}}{\mathrm{Sab}}=\frac{0.524}{0.342}=1.532
\end{aligned}
$$

The results of the above calculations show that the $\mathrm{t}$-calculate $<\mathrm{t}$-table is 1.532 $<1.657(\alpha=0.05$ and $\mathrm{df}=130)$, so it can be concluded that purchase intention has not been able to mediate the effect of halal certification on purchase decision.

\section{The Effect of Halal Marketing on Purchase Decision through Purchase Intention}

The effect of halal marketing on purchase decision shows that there is no influence between halal marketing and purchase decision. Khuwaroh et al. (2018) argue that promotion as an indicator in halal marketing does not affect on purchase decision. Promotions related to product prices show that consumers know the high price of products caused by high production costs, so when promotions such as discounts are 
held, they still do not care about this (Syukur and Nimsai, 2018). This contrary to Umah and Herianingrum (2018) that promotion as an indicator in marketing has a significant effect on purchase decision.

The effect of halal marketing on purchase intention shows that there is a significant influence between halal marketing and purchase intention. Awan et al. (2015) argue that halal marketing has the highest contribution in influencing the buying interest of Muslim consumers. Aziz and Chok (2013) show that promotion as a component of halal marketing has a significant effect on purchase intention.

Purchase intention as an intervening variable shows that there is a significant influence between purchase intention on purchase decision. To test the effect of mediation used Sobel test with formula following:

$$
\begin{aligned}
\mathrm{Sab} & =\sqrt{\mathrm{b}^{2} \mathrm{Sa}^{2}+\mathrm{a}^{2} \mathrm{Sb}^{2}+\mathrm{Sa}^{2} \mathrm{Sb}^{2}} \\
& =\sqrt{(0.760)^{2}(0.180)^{2}+(0.363)^{2}(0.297)^{2}+(0.180)^{2}(0.297)^{2}} \\
& =\sqrt{(0.578)(0.032)+(0.132)(0.088)+(0.032)(0.088)} \\
& =\sqrt{(0.019)+(0.012)+(0.003)} \\
& =\sqrt{0.033} \\
& =0.182 \\
\mathrm{t} & =\frac{\mathrm{ab}}{\mathrm{Sab}}=\frac{0.276}{0.182}=1.514
\end{aligned}
$$

The results of the above calculation show that the t-calculate $<\mathrm{t}$-table is $1.514<$ $1.657(\alpha=0.05$ and $\mathrm{df}=130)$, so it can be concluded that purchase intention has not been able to mediate the effect of halal marketing on purchase decision.

\section{CONCLUSION}

Based on the research results, the conclusions indicate that price perceptions have not significant effect on purchase intention and purchase decision. Product quality, halal certification, and halal marketing has a significant effect on purchase intention and not significant on purchase decision. Halal awareness is not significant on purchase intention and significant on purchase decision. Purchase interest as an intervening variable has a significant effect on purchase decision.

The effect of mediation can be seen in the effect of product quality on purchase decision through purchase intention as an intervening variable as full mediation. Another result is that the effect of halal certification and halal marketing on purchase decision has not been able to be mediated by purchase intention. Meanwhile, the mediation effect was not calculated on the effect of price perception and halal awareness on purchase decision through purchase intention.

The overall implication is that Muslim consumers with a good level of halal awareness will be careful to decide to buy food products by looking for information about these food products, especially Muslim consumers must attention and able to distinguish between the original halal logo and fake halal logo to guarantee has been consumed halal product based on own decision. The level of quality of halal food products is one of the factors considered by Muslim consumers so that it shows an 
opportunity for producers to produce halal food with good and consistent quality standards so that Muslim consumers are interested in making purchases and will make repeat purchases in the future. The Indonesian Council of Ulama (MUI) as the institution that is authorized to guarantee the halalness of a product can increase the potential of the halal food industry in Indonesia by providing easy administration of halal certification for producers. MUI is expected to provide socialization to the public regarding the importance of the LPPOM MUI halal logo on food product packaging so that consumers can guarantee the halalness of a food product they consume, as well as sales promotions that can influence Muslim consumers to purchase halal food.

\section{REFERENCES}

Ambali, Abdul Raufu \& Bakar, Ahmad Naqiyuddin. (2014). "People's Awareness on Halal Foods and Products: Potential Issues for Policy-makers. Procedia-Social and Behavioral Sciences, 121(September 2012), 3-25.

Anggadwita, G., Alamanda, D. T., \& Ramadani, V. (2020). "Halal Label vs Product Quality in Halal Cosmetic Purchasing Decisions". Ikonomika, 4(2), 227-242.

Angraini, Dwi \& Harwani, Yuli. (2020). "The Effect of Product Quality, Price Perception, and Promotion of Purchasing Decisions in Sari Roti in West Jakarta". Advances in Economics, Business and Management Research, 120 (Icmeb 2019), 296-301.

Ariffin, Shaizatulaqma Kamalul, et al. (2019). "Investigating the Factors Affecting Consumer Purchase Intention towards Halal Organic Food". 7(2), 162-188.

Aspan, Henry, et al. (2017). "The Effect of Halal Label, Halal Awareness, Product Price, and Brand Image to the Purchasing Decision on Cosmetic Products (Case Study on Consumers of Sari Ayu Martha Tilaar in Binjai City)". International Journal of Global Sustainability ISSN, 1(1), 55-66.

Awan, Hayat Muhammad, et al. (2015). "Factors Affecting Halal Purchase Intention Evidence from Pakistan's Halal Food Sector". Management Research Review, $38(2)$.

Ayuniyyah, Qurroh, et al. (2017). "Factors Affecting Consumers' Decision in Purchasing MUI Halal-Certified Food Products". Tazkia Islamic Finance and Business Review, 10(2), 122-143.

Aziz, Yuhanis Abdul \& Chok, Nyen Vui. (2013). "The Role of Halal Awareness, Halal Certification, and Marketing Components in Determining Halal Purchase Intention Among Non-Muslims in Malaysia: A Structural Equation Modeling Approach". Journal of International Food and Agribusiness Marketing, 25(1), $1-23$.

BPS. (2010). Retrieved from Penduduk Menurut Wilayah dan Agama yang Dianut. Jakarta: Badan Pusat Statistik. diakses pada 5 Februari 2020.

BPS. (2017). Retrieved from Penduduk Menurut Kelompok Umur dan Agama di Kota Semarang [Hasil SP2010]. Jakarta: Badan Pusat Statistik. diakses pada 15 Februari 2020.

BPS. (2019). Ringkasan Eksekutif Pengeluaran dan Konsumsi Penduduk Indonesia. Jakarta: Badan Pusat Statistik. diakses pada 7 Februari 2020.

Dinas Kependudukan dan Pencatatan Sipil Kota Semarang. (2019). Retrieved from Jumlah Penduduk Kota Semarang. diakses pada 5 Februari 2020.

Farlina, Norafni. (2017). "Consumer Behaviour, Perception and Planning Towards 
Halal Marketing". In Advances in Islamic Finance, Marketing, and Management, 271-307.

Fauzia, Diah Retno Sufi, Pangestu, E., \& Bafadhal, A. S. (2019). "Pengaruh Religiusitas, Sertifikasi Halal, Bahan Produk terhadap Minat Beli dan Keputusan Pembelian". Jurnal Administrasi Bisnis (JAB), 66(1), 37-46.

Ferdinand, Augusty Tae. (2006). Metode Penelitian Manajemen: Pedoman Penelitian untuk Penulisan Skripsi, Tesis dan Disertasi Ilmu Manajemen. Semarang: Undip Press.

Ghozali, Imam. (2017). Model Persamaan Struktural Konsep dan Aplikasi dengan Program AMOS 24 Update Bayesian SEM ed.7. Semarang: Badan Penerbit Universitas Diponegoro.

Fornell, Claes \& Larcker, David F. (1981). "Evaluating Structural Equation Models with Unobservable Variables and Measurement Error". Journal of Marketing Research, 18, 39-50.

Hadi, Sudharto P. (2007). Perilaku Konsumen. Semarang: Badan Penerbit Universitas Diponegoro.

Hair, Joseph F, et al. (2009). Multivariate Data Analysis 7th Edition. United States: Pearson Prentice Hall.

Hamdan, Haslenna. et al. (2013). "Purchasing Decisions among Muslim Consumers of Processed Halal Food Products". Journal of Food Products Marketing, 19(1), 54-61.

Huda, Nurul \& Muchlisin. (2014). "Pengaruh Label Halal Pada Makanan Fakultas Agama Islam". Suhuf, 26(1), 57-66.

Khuwaroh, Khumairotul, et al. (2018). "Analisis Pengaruh Label Halal, Keamanan Bahan, Promosi, dan Harga pada Produk Kosmetik Sariayu terhadap Keputusan Pembelian Konsumen. (Studi Kasus Pada Mahasiswi Fakultas Ekonomi Dan Bisnis Angkatan 2015-2018 Universitas Islam Malang)". Jurnal Professional FIS UNIVED, 5(1), 155-172.

Kotler, Philip \& Armstrong, Gary. (2012). Prinsip-Prinsip Pemasaran (13th ed.). Jakarta: Erlangga.

Lee, Hyun Joo \& Yun, Zee Sun. (2015). "Consumers' Perceptions of Organic Food Attributes and Cognitive and Affective Attitudes as Determinants of Their Purchase Intentions toward Organic Food". Food Quality and Preference, 39(2015), 259-267.

Maichum, Kamonthip. et al. (2017). "The Influence of Attitude, Knowledge, and Quality on Purchase Intention towards Halal Food: A Case Study of Young Non-Muslim Consumers in Thailand". IRA-International Journal of Management \& Social Sciences (ISSN 2455-2267), 6(3), 354.

Majelis Ulama Indonesia (MUI). (2009). Komisi Fatwa Majelis Ulama Indonesia tentang Penetapan Produk Halal. Jakarta: Majelis Ulama Indonesia. diakses pada 16 Februari 2020.

Majelis Ulama Indonesia (MUI). (2017). Sertifikat Halal MUI. halalmui.org diakses pada 8 April 2020.

Mannan, Muhammad Abdul. (1997). Teori dan Praktek Ekonomi Islam. Yogyakarta: PT. Dana Bhakti Prima Yasa.

Mas'ud, Fuad. (2017). Manajemen Bisnis Berbasis Pandangan Hidup Islam. Semarang: Undip Press.

Nafilah, Khumairotul, et al. (2015). "Pengaruh Kualitas Produk dan Harga terhadap 
Keputusan Pembelian dan Minat Beli sebagai Variabel Intervening (Study Kasus Pada Mahasiswa FEB Universitas Islam Malang Yang Mengkonsumsi Mie Instan)". Jurnal Riset Manajemen, 53(9), 1689-1699.

Nurcahyo, A., \& Hudrasyah, H. (2017). "The Influence of Halal Awareness, Halal Certification, and Personal Societal Perception Toward Purchase Intention: a Study of Instant Noodle Consumption of College Student in Bandung". Journal of Business and Management, 6(1), 21-31.

Nurhasanah, S., Munandar, J. M., \& Syamsun, M. (2018). "Faktor-Faktor yang Mempengaruhi Minat Beli Produk Makanan Olahan Halal pada Konsumen". Jurnal Manajemen Dan Organisasi, 8(3), 250.

Peter, J. Paul \& Olson, Jerry C. (2013). Perilaku Konsumen dan Strategi Konsumen, 9th ed, terj. Diah Tantri Dwiandani. Jakarta: Salemba Empat.

Phan, The Anh \& Mai, Phuong Hoang. (2016). "Determinants Impacting Consumers' Purchase Intention: The Case of Fast Food in Vietnam". International Journal of Marketing Studies, 8(5), 56.

Rachmawati, Hizrina \& Muflikhati, Istiqlaliyah. (2017). "The Influence Of Perception On Purchasing Decision Of Soy Sauce Sachet In Rural And Urban Area". Journal of Consumer Sciences, 2(2), 1.

Rahmaningtyas, A., Hartono, S., \& Suryantini, A. (2017). "Faktor-Faktor Yang Mempengaruhi Pembelian Makanan Khas Daerah Secara Online". Agro Ekonomi, 28(2), 189-204.

Rianto, Nur \& Amalia, Euis. (2014). Teori Mikroekonomi: Suatu Perbandingan Ekonomi Islam dan Ekonomi Konvensional (2nd ed.). Jakarta: Kencana.

Rois, Ekawati Labibah Handayani. (2016). "Pengaruh Religiusitas, Norma Subyektif Dan Perceived Behavioral Control Terhadap Niat Membeli Produk Makanan Ringan Berlabel Halal (Studi Pada Mahasiswa Muslim Fakultas Ekonomi Universitas Negeri Yogyakarta)". Eprints Uny, 1-187.

Satria, Arief Adi. (2017). "Pengaruh Harga, Promosi, dan Kualitas Produk Terhadap Minat Beli Konsumen Pada Perusahaan A-36". Jurnal Manajemen Dan Start-Up Bisnis, 2(1), 45-53.

Setyaningsih, Eka Dyah \& Marwansyah, Sofyan. (2019). "The Effect of Halal Certification and Halal Awareness through Interest in Decisions on Buying Halal Food Products". Syi ar Iqtishadi : Journal of Islamic Economics, Finance, and Banking, 3(1), 64-79.

Shaari, Jamal Abdul Nasir \& Arifin, Nur Shahira M. (2010). "Dimension of Halal Purchase Intention A Preliminary Study". In American Business Research Conference: Vol. 6(4), 444-456.

Sugiyono. (2017). Metode Penelitian Kualitatif, Kuantitatif, dan R\&D. Bandung: Alfabeta.

Syukur, Muhammad \& Nimsai, Suthep. (2018). "Factors influencing the purchase intention of halal packaged food in Thailand". International Journal of Supply Chain Management, 7(4), 1-6.

Tawas, Hendra \& Pandensolang, Josiel. (2015). "Pengaruh Diferensiasi, Kualitas Produk Dan Ekuitas Merek Terhadap Keputusan Pembelian Coca-Cola Pada Pt. Bangun Wenang Beverges Company Di Manado". Jurnal Riset Ekonomi, Manajemen, Bisnis Dan Akuntansi, 3(3), 1113-1124.

Thomson Reuters \& DinarStandard. (2018). State of the Global Islamic Economy Report 2018/19. Dubai International Financial Centre, 112. 
Tjiptono, Fandy. (2002). Strategi Pemasaran. Yogyakarta: Andi.

Umah, Khurul Aimmatul \& Herianingrum, Sri. (2018). "The Influence of Halal Label, Promotion and Price Toward Purchasing Decision on Over the Counter Medicine". SSRN Electronic Journal.

Varinli, nci, et al. (2016). "Exploring the Factors Affecting Purchase Intention of Halal Certified Foods in Turkey: A PLS-Path Modeling Study". European Journal of Business and Management, 8(4), 68-78.

Widyastuti, S., \& Said, M. (2017). "Consumer Consideration in Purchase Decision of SPECS Sports Shoes Product through Brand Image, Product Design and Price Perception". International Journal of Supply Chain Management. 6(4), 199-207.

Yunus, Nor Sara Nadia Muhamad, et al. (2014). "Muslim's Purchase Intention towards Non-Muslim's Halal Packaged Food Manufacturer". Procedia - Social and Behavioral Sciences, 130, 145-154.

Yussof, Mohd. (2004). Halal Certification Scheme (11th ed.). Malaysia: Standard and Quality News. 